Горбенко А. Ю.;

Головченко О. В.;

Голобородько М. Ю., к.т.н., с.н.с.

Центр воєнно-стратегічних досліджень Національного університету оборони України імені Івана Черняховського

\title{
Аналіз досвіду створення та бойового застосування систем оперативного управління
}

Резюме. У статті проведено аналіз існуючих систем оперативного управління, які використовуються у провідних арміях країн світу для обгрунтування рекомендацій щодо побудови вітчизняної моделі управління військами.

Ключові слова: C4ISR, системи зв’язку та інформатизації, система управління.

Постановка проблеми. Зважаючи на досвід проведення Антитерористичної операції на територіях Донецької та Луганської областей постає нагальна необхідність у забезпеченні бойових підходів, що виконують завдання багатофункціональною інформаційноуправляючою системою, яка б інтегрувала функції управління військами, зброєю, розвідкою, радіоелектронною боротьбою, а також зв'язку, навігації, орієнтування і розпізнання. При проведенні АTO за рахунок волонтерських організацій було створено ряд програмних продуктів, які частково вирішували завдання системи управління боєм.

Враховуючи зазначене, окремі підрозділи використовують дані системи проте взаємодія цих програмних продуктів між собою $є$ проблематичною.

Виходячи 3 цього виникає проблема аналізу існуючих систем управління для створення інтеграційної платформи та системи управління військами, яка може бути використана під час виконання бойових завдань, враховуючи взаємодію між різними родами та видами військ.

Аналіз основних досліджень i публікацій. Сучасні методи ведення мережево-центричної війни вимагають створення систем управління військами та силами.

Сили, які об'єднані надійними мережами отримають можливість обміну інформацією якісно нового рівня. Обмін інформацією підвищує якість загальної інформованості особового складу на полі бою. Як результат загальна ситуаційна інформованість дозволяє забезпечити необхідну співпрацю та синхронізацію, що підвищує стійкість та швидкість передачі команд, що у свою чергу дозволяє більш ефективно виконувати бойові завдання.

Успішне виконання завдань грунтується на значно меншій тривалості бойового циклу “виявлення-впізнання-цілевказання-ураження" порівняно з супротивником, на більш точних та повних відомостях про угруповання супротивника, що протистоїть [1].

Переважна кількість науковців, які вели розробки по даній проблемі прийшли до висновку, що для ефективного вирішення бойових завдань необхідні нові програмні продукти, які би дозволили вести обмін розвідувальною інформацією та передавати команди в режимі реального часу, а також розширити функціонал для більш якісного аналізу противника, що дозволить отримати перевагу при залученні меншої кількості особового складу та техніки.

Метою статті є розгляд існуючих систем управління військами збройних силах провідних країн для подальшої поетапної реалізації програми створення інформаційної мережі поля бою в Збройних Силах України.

Виклад основного матеріалу. Запропоновано нову архітектуру мобільної компоненти мереж зв'язку ЗСУ, яка враховує: досвід розвитку тактичних систем зв'язку провідних країн світу; сучасні вимоги процесу управління військами та відповідні вимоги до систем зв'язку тактичного рівня; сучасний рівень розвитку безпровідних телекомунікаційних технологій цивільного призначення.

У США ведуть інтенсивну роботу по створенню єдиної багатофункціональної інформаційно-управляючої системи, яка інтегрує функції управління військами, зброєю, розвідкою, радіоелектронною боротьбою, а також зв'язку, навігації, орієнтування i розпізнання - C4ISR (Command, Control, 
Communications, Computers, Intelligence, Surveillance \& Reconnaissance). Архітектура C4ISR представлена на рис. 1.

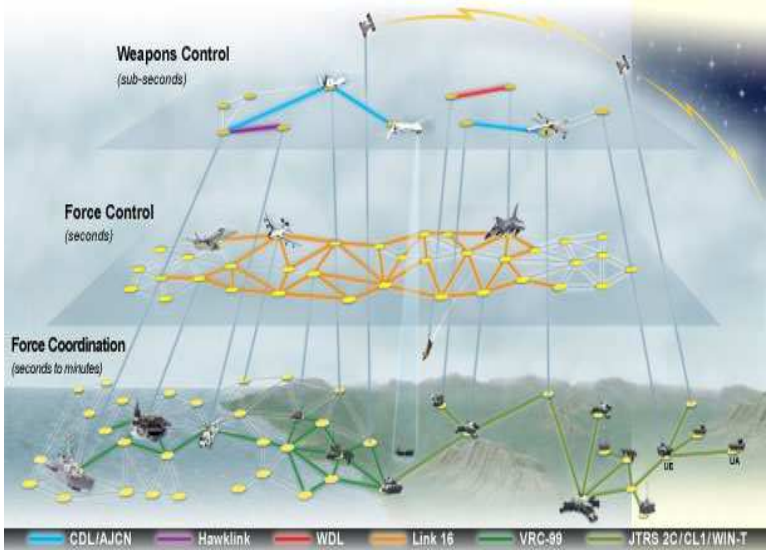

У збройних силах провідних країн вже запропоновано поетапну реалізацію програми створення інформаційної мережі поля бою (WIN-T - Warfighter Information Network Tactical), що передбачає реорганізацію дивізій

\section{$\mathrm{y}$}

“комп’ютеризовані” (рис. 2).

Метою реорганізації $\epsilon$ зменшення бойового i чисельного складу дивізії 3 одночасним зростанням іiі бойової ефективності за рахунок підвищення мобільності, досягнення абсолютної переваги в інформаційному забезпеченні і розвідувальних можливостях.

\section{Pис. 1. Архітектура C4ISR}

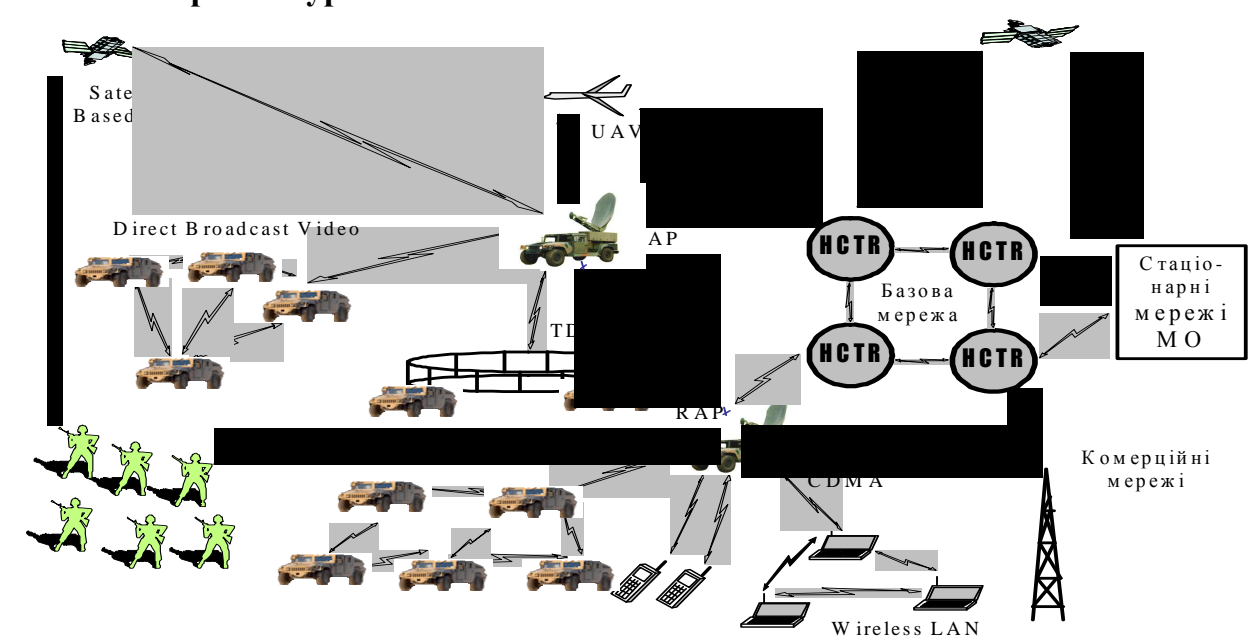

Pис. 2. Архітектура WIN

Дана програма відображає сутність безпровідних ЛОМ (WLAN), які дозволять побудови перспективних систем зв'язку розвинених країн світу.

У Табл. 1 показані етапи впровадження комерційних технологій і стандартів у системи військового зв'язку тактичної ланки управління (ТЛУ) в рамках програми WIN-T [2].

У першу чергу планувалося: замінити існуюче устаткування MSE/TPN (Mobile Subscriber Equipment/Tactical Packet Network) мережі на комерційне (IP маршрутизатори, мости тощо); впровадити комерційні рішення

здійснювати переміщення абонентів у межах 3 миль; забезпечити сервіси персонального зв'язку (PCS - Personal Communication Services); почати використання протоколу IPv.6.

До цього часу передбачалося об'єднати різнорідні мережі JTIDS, EPLRS, SINGARS, NTDR у єдину - тактичний Інтернет TI (Tactical Internet) за допомогою шлюзів TMG (Tactical Multinet Gateways) i маршрутизаторів INC (Internet Controller), що використовують протоколи TCP/IP.

Таблиця 1

\begin{tabular}{|l|l|}
\hline \multicolumn{1}{|c|}{ До 2013 p. } & \multicolumn{1}{|c|}{2013 p. $\rightarrow$} \\
\hline IP телефонія & Цілком комерційна основа. \\
Реалізація технологій СDMA, MANET & Нові рішення мобільності й мережевого керування, \\
Високий рівень засекречування & мультимедійні та IP протоколи \\
Автоконфігурація мережі & \\
Групова передача (multicasting) & \\
\hline
\end{tabular}

Можливим напрямком підвищення показників радіомереж тактичного рівня, в умовах скорочення бюджетних асигнувань на оборону, $\epsilon$ впровадження сучасних технологій і стандартів бездротового зв'язку цивільного призначення. Такий підхід повністю відповідає концепції COTS (commercial off-theshelf), яка досить широко використовується навіть у арміях розвинених країн світу. 
Однією 3 найбільш перспективних технологій побудови мобільних підсистем інформаційного обміну, що може бути використана у системах зв'язку спеціального призначення $\epsilon$ технологія стандарту IEEE 802.16 (WiMAX), яка забезпечує високу пропускну спроможність, завадозахищеність та підтримку сучасних технологій забезпечення якості обслуговування при прийнятних енергетичних параметрах та зоні радіопокриття.

Вимоги до перспективних радіо засобів:

- висока пропускна спроможність радіоканалу (>200Кб/c);

- багатодіапазонність

багатофункціональність

(FDMA/TDMA/CDMA) роботи;

- програмуємість всіх видів та режимів роботи;

- самоорганізація мережі (режим Plugand-Play);

- інтелектуальність, децентралізованість і оптимізація функцій управління мережевими ресурсами (маршрутизація, навантаження, топологія, радіоресурс, безпека тощо);

- робота в різних мережах

(стільникових, мобільних) і з різними видами трафіку (мова, дані, відео);

- наявність системи позиціонування;

- спрямовані (МIMO) антени;

- робота в русі;

- модульність виконання і відкрита

архітектура;

- низьке енергоспоживання;

- максимальне використання цивільних технологій та протоколів.

У подальшому розвитку бездротових технологій необхідно поставити на меті повну децентралізацію мережі передачі інформації у тактичній ланці управління шляхом використання принципово нових технологій [3], за яких основним елементом системи буде вузол мережі - радіотермінал (переносний комп'ютер, який оснащений радіомодемом) 3 функціями маршрутизатора.

Таким чином одразу вирішиться питання мобільності, захищеності цілісності мережі від зброї масового ураження, та мінімальна участь людини в процесі управління сучасним боєм. Аналог даної схеми представлений на рис. 3.
На даний час використання можливостей http-послуг $є$ пріоритетним для багатьох розвинених країн світу. На основі вище цивільних протоколів були створені автоматичні системи управління військами.

У збройних силах Данії дана АСУ "SitaWare" [4] (рис. 4.), використовується для передачі тактичних графіків, коротких географічних оглядів, записок та нотацій. Здійснюється співпраця командирів та штабів через електронну пошту, форуми, чати, 3 можливістю передачі військових повідомлень, оголошення про перехід до інших ступенів бойової готовності.

i Дані про зміну тактичної обстановки відображається на моніторах командирів підрозділів, які в свою чергу можуть віддавати накази та розпорядження як голосом так $\mathrm{i}$ передачею даних та відеоповідомлень.

На даний час, у розпорядженні Збройних Сил України існують дві аналогічні системи управління військами: АСУ ПД “Дніпро" та АCУ "Карпати", які знаходяться на етапі вдосконалення та доопрацювання.

Прикладом застосування http-послуг у збройних силах США $є$ автоматизована система управління військами "Army Battle Command System" (рис. 5).

Застосування даних систем управління значно збільшує оперативну гнучкість системи зв'язку, об'єднаність інформації, що циркулює у АСУ, що призводить до синхронізації зусиль під час ведення бойових дій. У перспективі розвитку подібних систем $є$ доведення мобільних вузлів до кожного військовослужбовця, який знаходиться на полі бою, використання отриманої ним інформації у всіх ланках управління у масштабі реального часу.

3 цією метою було створенно ІП “Дельта" для забезпечення інформаційної взаємодії та сумісності між системами різного функціонального призначення, побудованими на різних програмно-апаратних платформах із застосуванням широкого спектру інформаційних технологій та геоінформаційних платформ, у тому числі застарілих, за рахунок застосування єдиного протоколу інформаційного обміну, який прийнято у країнах-членах НАТО. 


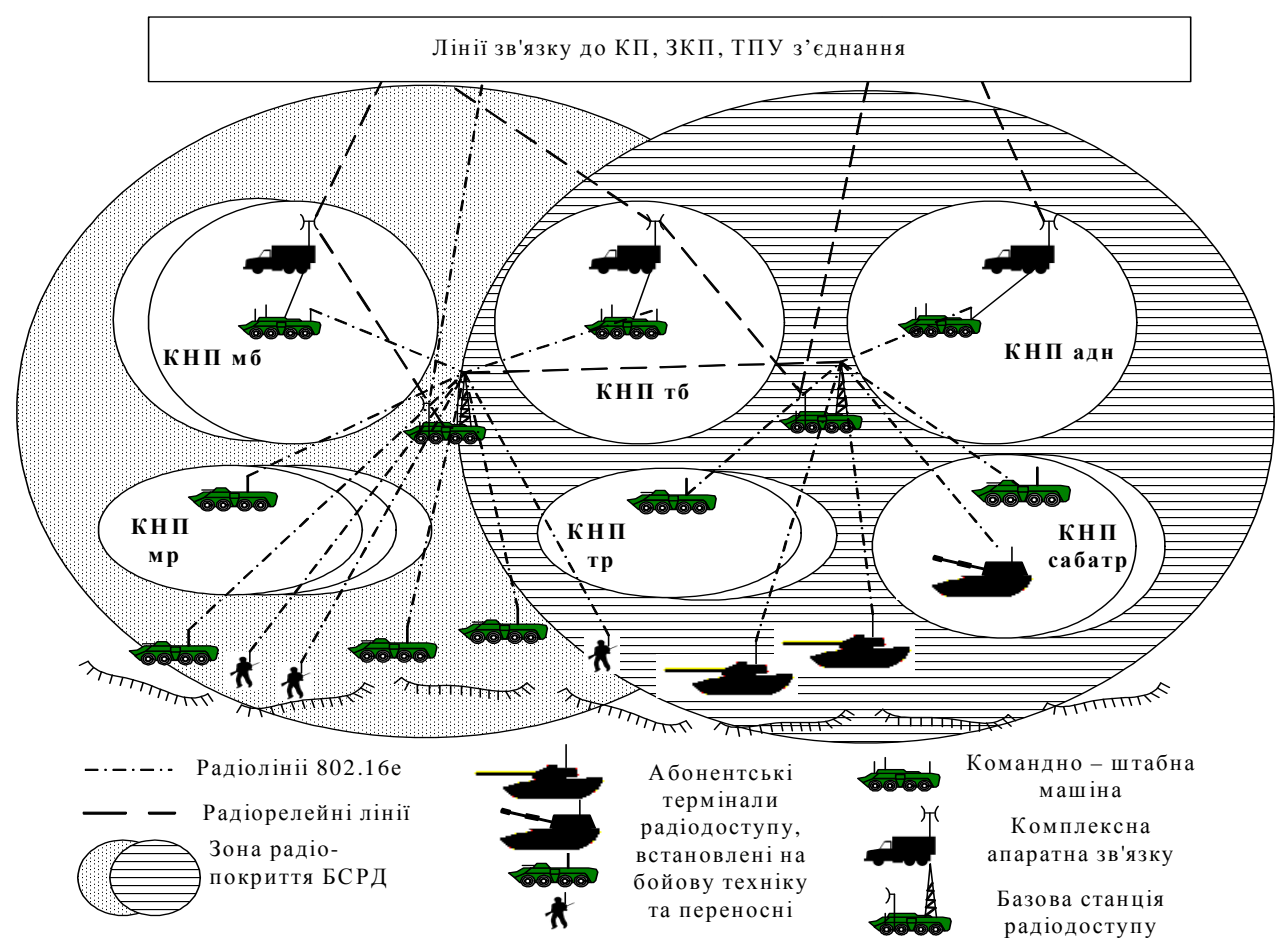

Рис. 3. Варіант підсистеми зв'язку та інформаційного обміну мобільних користувачів системи зв'язку та інформатизації ТЛУ СВ на основі обладнання стандарту IEEE 802.16е-2005

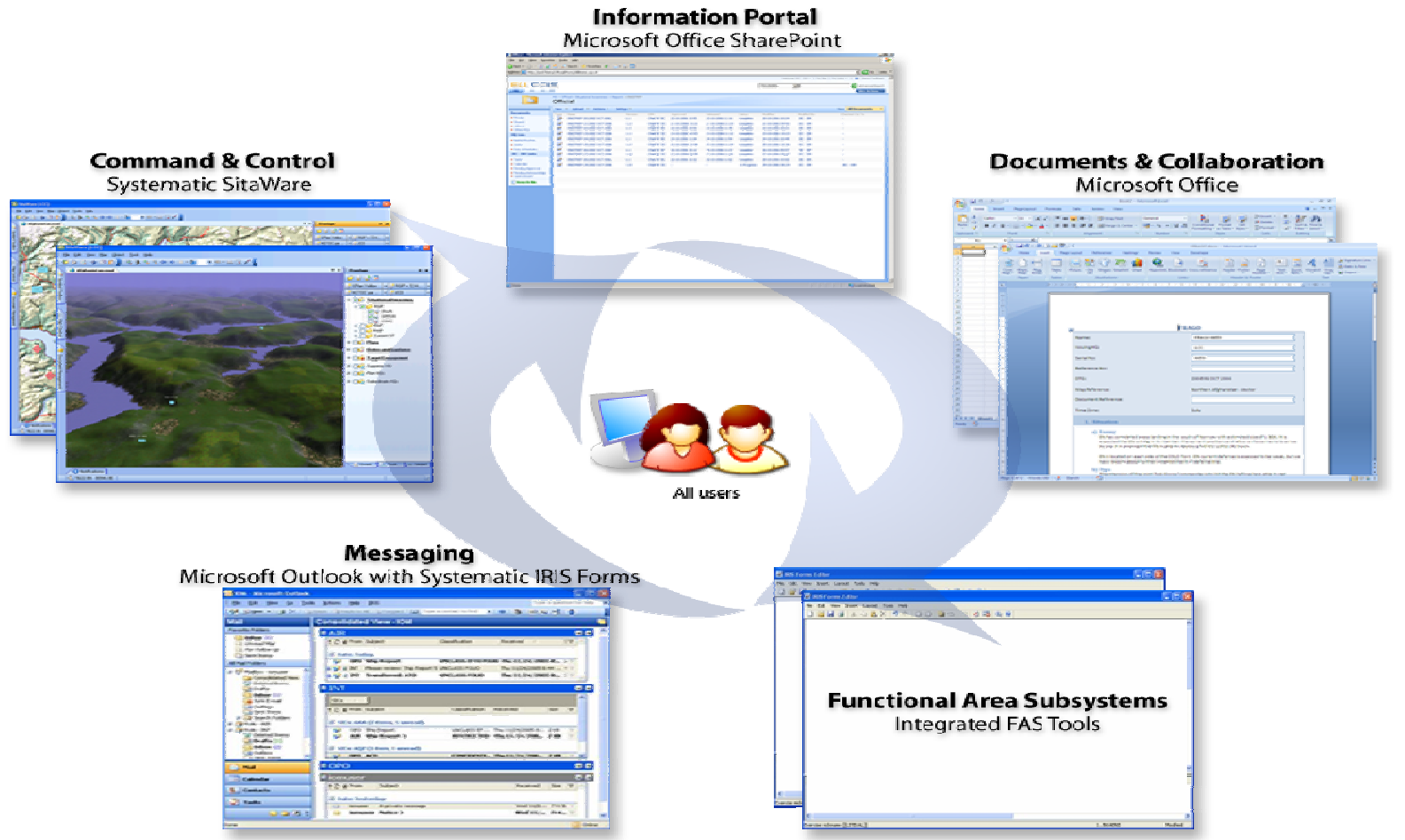

Рис. 4. Інтерфейс АСУ збройних сил Данії "SitaWare”

Основні завдання ІП “Дельта”:

інтеграція різноманітних джерел інформації у єдиний інформаційний простір Збройних Сил України;

оброблення (приведення до встановленого вигляду) та видача інформації на автоматизовані робочі місця (далі - АРМ) посадових осіб органів військового управління (військових частин); інформаційне забезпечення процесів загальновійськового планування та управління ними;

надання доступу до єдиного інформаційного простору посадовим особам органів військового управління (військових частин, підрозділів);

забезпечення взаємодії 3 іншими військовими формуваннями та правоохоронними органами України в рамках єдиного інформаційного простору.Програмний модуль збору, аналізу та обробки інформації (Дельта 
монітор) призначений для вирішення комплексних завдань візуалізації даних від різних джерел, відображення оперативної обстановки на електронній карті в режимі реального часу та для нанесення оперативної обстановки на неї. Він забезпечує візуалізацію інформації, ऑii збереження, оброблення та розповсюдження.

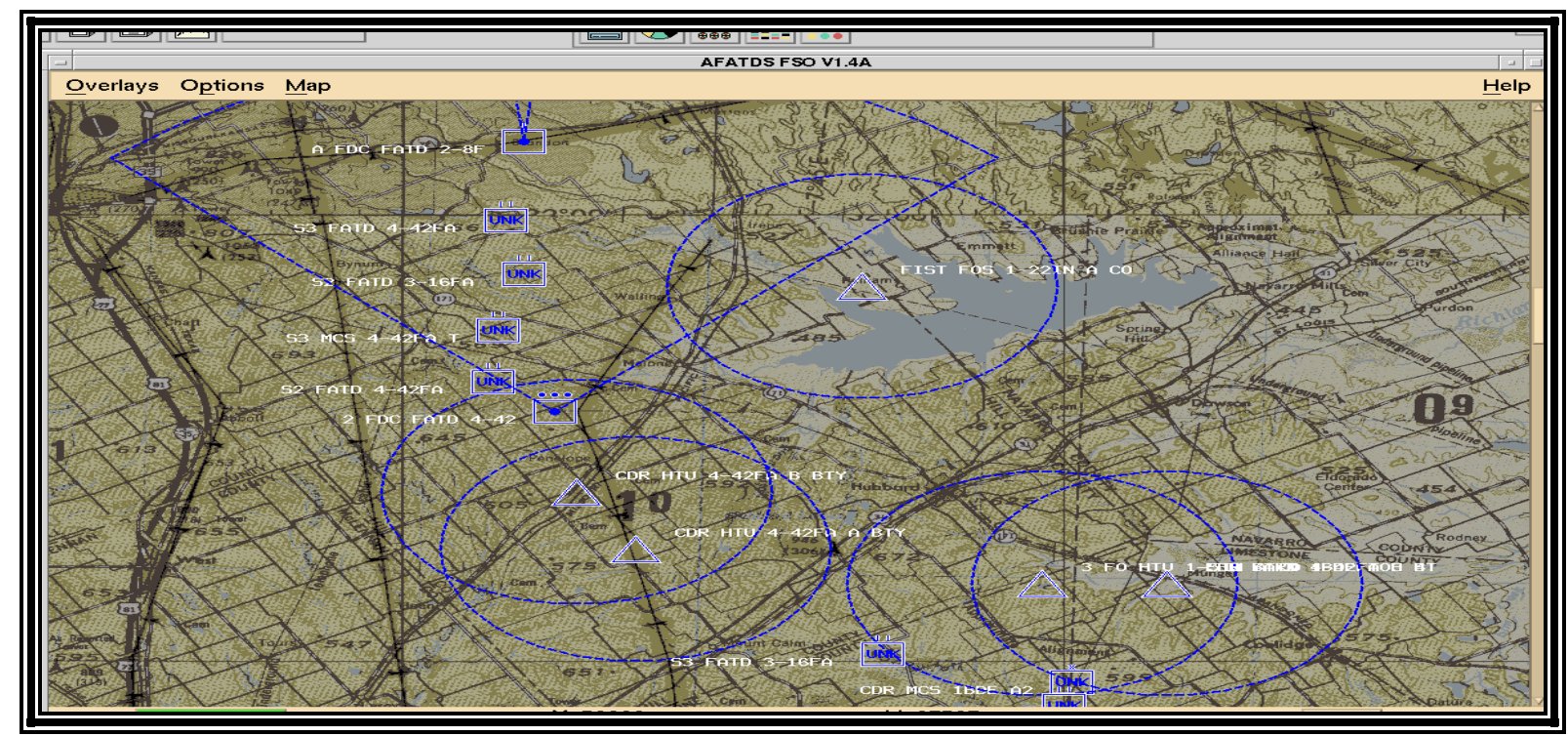

Рис. 5. Інтерфейс АСУ збройних сил США “Army Battle Command System”

Висновки. Висновок: існуючі цивільні технології бездротових мереж зв'язку мають стати основою для створення мобільних радіомереж тактичного рівня. Застосування запропонованої архітектури мобільної компоненти :

використовують різні програмні продукти та системи зв'язку, що дозволить зменшити час на прийняття рішення та підвищить оперативність бойових підрозділів.

\section{СПИСОК ВИКОРИСТАНОЇ ЛІТЕРАТУРИ}

- призведе до появи принципово нових способів ведення бойових дій, змінить форми та способи управління військами, а також дозволить значно збільшити бойову ефективність військ.

- дозволить значно підвищити основні характеристики системи зв' язку та автоматизації (бойову готовність, живучість, мобільність, пропускну спроможність тощо).

Використання інтеграційної платформи

1. Мережева війна XXI-го століття. Режим доступу: http://www.webcitation.org/6HxlGt7F3.

2. Романюк В. А. Напрямки розвитку тактичних систем зв'язку // II Науково-технічна конференція. ВITI. - К. :ВІТІ НТУУ “КПІ", 2004. - С. 23-33.

3. Other Architectures and Frameworks. Режим доступу: http://pubs.opengroup.org/architecture/togaf8-

doc/arch/chap37.html

4. Seaware C4I suite. Режим доступу: https://systematic.com/defence/products/c2/sitaware/

Дельта забезпечить взаємодію підрозділів, що

Стаття надійшла до редакції 26.06.2017

Горбенко А. Ю.;

Головченко А. В.;

Голобородько М. Ю., к.Т.н., с.н.с.

Центр военно-стратегических исследований Национального университета обороны Украины имени Ивана Черняховского, Киев

Анализ опыта создания и боевого применения систем оперативного управления

Резюме. В статье проведен анализ существующих систем оперативного управления, используемых в ведущих армиях стран мира для обоснования рекомендаций по построению отечественной модели управления войсками.

Ключевые слова: C4ISR, системы связи и информатизации, система управления.

\section{A. Gorbenko;}

A. Golovchenko;

M. Goloborodko, Ph.D, senior researcher

Center for Military and Strategic Studies of the National Defence University of Ukraine named after Ivan Chernyhovsky, Kyiv

Analysis of the experience of the creation and operational use of operational control systems

Resume. The article analyzes the existing systems of operational management that are used in the leading armies of the countries of the world, how to use experience for building a national model of troop control.

Key words: C4ISR (Command, Control, Communications, Computers, Intelligence, Surveillance \& Reconnaissance), communication and information systems, management system. 